\title{
Hodnota v stratégii autora a interpretácie umeleckého textu
}

\section{Value in Author's Strategy and Interpretation of Artistic Text}

\author{
Viera Žemberová \\ (Prešov, Slovensko)
}

\begin{abstract}
:
The paper focused on the Russian prose of the authors who, personally, from time to time or with generational insight, respond to the course and consequences of personal, political, military and social events in Russia at the beginning of the 2oth century. The authors of the prose texts coincide with the events of the tenth to the thirties as authentic experience, observe the existential, moral, philosophical and confessional aspect of the demise of old Russia and the values enshrined in the political power of Soviet Russia.
\end{abstract}

\section{Key words:}

author; substance; themes; history; events; Russian prose; value; ideology; culture; tradition; character 
So štruktúrou a významom termínu hodnota sa spoločenské vedy vyrovnávajú latentne, navyše aj špecificky voči základnému predmetu svojho výskumu; jednak pre jeho ustálený, štandardný a do univerza precizovaný obsah, ale aj pre jeho schopnost’ prejavit’ sa ako jav špecifický, časovo ${ }^{1}$ a vývinovo limitovaný. Napokon aj to spôsobuje a znamená, že sa jeho prítomnost̉ a prirodzená vývinová aktualizácia v spoločenských vedách vníma diferencovane. ${ }^{2} \mathrm{~S}$ termínom hodnota sa spájajú pri jeho precizovaní dalšie komponenty, ktoré ho užšie vymedzujú ako následok jeho technickej, sociálnej a kultúrnej tendencie (povaha, funkcia), a popri špecifikácii hodnoty medzi komponentmi zavážia norma, princíp, kritérium, funkcia, zhodnocovanie, vykonatelnost', či zodpovednost'. V tejto súvislosti sa pri komponentoch a ich uplatnení v mozaike spoločenských vied účinne presadí repetovaná etická hodnota riešeného, či aplikovaného komponentu konkrétneho problému v spoločenskovednom výskume.

Literárna veda venuje sústredenú pozornost̉ podstate a inováciám estetickej, etickej, poetologickej a noetickej hodnoty umeleckého artefaktu, ktorá obsiahne a vymedzuje lierárnoestetický program odvíjaný od látky a strategicky organizovaný kompozíciou textu predovšetkým noeticky rozvinutý prostredníctvom tematiky autorovej stratégie. Autorovo poetologické zázemie sa naplno uplatní v koncepte nazeracej stratégie a v jej aplikácii do stratégie konkrétneho umeleckého textu, čím sa obsiahne, popri estetickej a etickej hodnote predovšetkým ich dotvorenie noetickej, emotívnej a zážitkovej ambície pôvodného autorovho zámeru. Autorova stratégia hodnoty môže, ale aj nemusí znamenat', že ide o ustálený koncept, teda ním rešpektovaná a tematicky či motivicky latentne utvrdzovaná umelecká alebo spoločenská hodnota, ktorá (príčinne predpokladáme) prechádza prirodzenými obmenami alebo aplikovanými aktualizáciami, a tie sú (môžu byt') ad hoc poetologicky a noeticky motivované, čo naznačuje $\mathrm{i}$ to, že „Hodnoty jsou $\mathrm{v}$ literatuře vytvorěny a $\mathrm{v}$ literární vědě formulovány, zdůvodňovány a hájeny $\mathrm{v}$ hodnototvorném procese, $\mathrm{v}$ němž probíhá evaluace a revaluace: co bylo vysoké, klesá, co bylo nízko, se zvedá. [...]. Problém hodnoty a hodnototvorného procesu a axiologie v literatuře se stal nejednou objektem literárněvědných výzkumů i v těch vědeckých školách, v nichž nebyl prvoradým cílem. [...]. Problém hodnoty, jenž je přirozenou součástí literatury a literární vědy, je

1 „Hodnoty se předávají z generace na generaci prakticky v nezměněné podobě. Jelikož jsou hodnoty osvojovány v raném věku, většina hodnot zůstává v podvědomi“" [PRUDKÝ 2009, 60].

2 „Tento pojem se používá v mnoha souvislostech a s mnoha výklady, nicméně vždycky se má na mysli něco podstatného pro existenci jevu či procesu, o jehož hodnotách se diskutuje. A vždycky do obsahu toho, co myslíme hodnotami, vstupuje i zkušenost a sebareflexe. Hodnoty mají řadu rovin [...]. Jde o jeden $\mathrm{z}$ rozhodujících zdrojů toho, jak daný jedinec vidí svět. A totéž v jistém smyslu řící i o hodnotách nějaké skupiny, společenstí, národa, kultury či civilizace“ [PRUDKÝ 2009, 7]. Enumeračne sa pracuje s temínom hodnota (popri dalších spoločenskovedných výskumoch) v ekonomii, antoropológii, kulturológii, psychológii, sociológii, vo filozofii, axiológii, v estetike, literárnej estetike, v literárnej vede [PRUDKÝ 2009, 7, 9]. 
tedy vnitřně rozrůzněný, vztahový a může se s ním různě nakládat. [...]. Může to být tedy naopak krize literární hodnoty, rozkolísání, rozptýlení, rozprostření, zamlžení hodnotové hierarchie lakmusovým papírkem rozsáhlejších společenských změn a často je i anticipuje" [POSPÍŠIL 2013, 72, 75].

Literárna veda pracuje s hodnotami, ktoré sa utvárajú pričinením literárnej estetiky, poetológie a filozofovaním; tie sú a priori zahrnuté do autorovej stratégie ako jej profilácia a prejav neprenosnosti konkrétnej tvorivej literárnej dielne. Napokon autorova (tematická, poznávacia, ideologická) konštrukcia znamená i to, že estetickú hodnotu ,je možno popsat jako [...] významný proces na jehož vzniku nebo dění participuje estetické osvojováni si světa člověkem. [...]. Právě na rozdílnych hodnotách do značné míry spočívá variabilita mezi kulturami. Hodnoty jedince jsou výrazně ovlivněny konkrétní kulturou, v niž žije. [...]. Estetická hodnota integruje hodnoty mimoestetické, noetické, politické, erotické, etické atd. Vzniká a vytváří se v estetickém zážitku [...]" [DOHNAL 2012, 33]. V stratégii autora sa estetická, poznávacia a zážitková hodnota umeleckého textu kompozične utvárajú a súbežne konštruujú vo vnútrotextovom priestoru. $\mathrm{V}$ ňom sa v súlade s literárnou estetikou, poetológiou a noetikou autora dostáva do kontaktu neliterárny a literárny svet, ${ }^{3}$ na čo reaguje výber genologického podložia pre umelecký text.

Spoločenské a politické zlomy v spoločenských ustrojeniach ludstva najčastejšie pozývajú na ponorné pohlady aj do kultúrnych dejov, tie sa v okamihu, ked’ sa o ne začnú zaujímat jednotlivé súčasti spoločenských vied, už vypovedajú iba o hodnote a hodnotení toho, čo ju spája s minulostiou, s dobovým nazeraním na hodnoty, aby sa vymedzila javová a hodnotová, ale aj aplikačná spojnica $\mathrm{k}$ tým entitám, ktoré sa presadia, udržia sa, prípadne sa obmenia a súčasnosṫ', jej prax, ich bude rešpektovat. Podstatou vymedzovania hodnoty v umeleckom texte sa stáva výskum a výklad híbky a súvislostí poznania konkrétnej spoločenskej, historickej „doby“ vdaka dostupnému materiálu o nej a postupmi literárnovedného či umeleckého (mimoliterárneho) výkladu toho a o tých, čo svoj čas prijali, vkladali do neho „svoje“ hodnoty, tie (pre)vytvárali a ponúkali do budúcnosti ako relevantné poznanie minulosti o sebe a svojej dobe, ako to podložie, ktoré utvára podmienky na další pohyb, ba viac, mení sa na výzvu ako možno napredovat v civilizačnom rozvíjaní tvorivého človeka a jeho spoločenstva. Zrelost’ spoločnosti a dôkladnost i „dôveryhodnost" poznania prinášaného spoločenskými vedami sa overuje v čase a v pokračujúcom, či znova iniciovanom výskume, hoci vedy o vývine spoločnosti (minulé i súčasné) jestvujú a „pracujúu spoločne práve s časom rozmieňaným na všeobecné i zvláštne $\mathrm{v}$ živote ludí a sú odvíjané od toho, čo život

3 Reálny svet versus fikčný svet - v naratológii sa pracuje s pojmami - postava, udalost', prostredie, situácia, úloha, ujma, odplata, napadnutie, obet’, vyjednávanie, zlepšenie, zhoršenie, protivník spojenec - kategórie, ktoré predpokladajú jestvovanie skutočných prototypov, reálnych náprotivkov [ČERVENKA 2005, 807-808]. 
vo svojej dennej členitosti a rozličnosti početných dejov, javov, úkonov, rozhodnutí a riešení prináša nielen pre jednotlivca, ale vyžaduje od spoločnosti.

Čas na život si môže v najjednoduchšej hre „kto z koho“ dovolit schému na stretanie sa mocných a slabých, podlých a čestných, teda na preživajúce nástroje a dôsledky zla a na zisky dobra. Niet takej dejinnej doby, nenájdeme takú spoločnost̉ v histórii ludstva, ktorá by nestála pred volbou, ako sa vyrovnat so silami zla premeneného na politickú moc ovládajúcu spoločnost̉, nech si jej nástupkyňa - stará/nová - nasadí akúkolvek masku, ktorá azda najvýraznejšie vystihne čas premenený na deje prežité „খšetkými“ a na „dejiny“ obsiahnuté v odlišných príbehoch jednotlivcov. „Dôležitých vecí, ktoré spisovatel' musí vyslovit, nie je tak vela." [FELDEK 1982, 109].

Udalosti prvých dvoch desatročí minulého storočia na európskom kontinente spája aj pri ich odlišnej etnickej, národnej, geografickej realizácii dotyk a dôsledky navodené závažnými spoločenskými, predovšetkým politickými, geopolitickými, vojenskými, sociálnymi, ekonomickými a kultúrnymi zmenami. Zánik starého a vznik nového sú koniec a počiatok dramaticky po sebe nasledujúcich udalostí, ktoré zmenili „tvár“ a tvar európskeho kontinentu. Pohyby, ktoré sú začiatkom konca cárskeho Ruska dostali do pohybu kontinent a vyústili do takých vojenských a vojnových stretov, aby natrvalo politicky, etnicky a ekonomicky zmenili kontinent, vniesli do jeho geografickej mapy nové štátne útvary, emancipovali autonómne národné a kultúrne spoločenstvá.

Politické, ekonomické a ideologické, ale predovšetkým mocenské a vojenské pohyby v cárskom Rusku zrýchlili život v krajine, zmenili vztahy a zmýšlanie európskeho kontinentu o Rusi a vice versa, zasiahli do života mnohonárodného spoločenstva aj jednotlivcov. Strata v žitej konvencie v živote a v mysli staroruského spoločenstva zánikom cárskeho systému, jeho spoločenských štruktúr a hodnotového retazca prepájajúceho výkonnú a duchovnú moc krajiny, dravý až krutý (revolučný) rozklad spoločensky tradovanej a vžitej normy, mravný a nimi udržiavaných hierarchických návykov/zvykov uplatňovaných po generácie $\mathrm{v}$ právne a sociálne diferencovanom národnom a spoločenskom systéme, ktorý tradične uplatňovala politická, cirkevná a ekonomická „vrchnost" v každodennom živote krajiny až po odveké a pevne vžité pravidlá a praktiky $\mathrm{v}$ obyčajnom živote prostého obyvatelstva. Následkom a súčastou dravých spoločenských, ekonomických, vojenských - cársky/starý/vžitý komponentov štátneho a spoločenského systému, ktoré popri medzinárodných reáliách na kontinente od začiatku 20. storočia iniciovali dramatické zmeny, stala sa skutočnost̉ou aj fatálna dráma zneisteného jednotlivca a vertikálna kríza národného spoločenstva, ktorú od jej súčasníkov ${ }^{4}$ až po súčasnost ${ }^{5}$ zachytávala - a dodnes tak

4 Za literárne východiská pri zobrazení zlomových udalostí v Rusku považujeme pre náš príspevok práce Vasilija Vasilieviča Rozanova (1856 - 1919), Ivana Sergejeviča Šmeljova (1873 - 1950), Vladimíra Vladimiroviča Nabokova (1899-1977).

5 Olga Alexandrovna Slavniková (*1957), román 2017. 
presvedčivo činí - ruská a (revolučná) sovietska kultúra, ide obzvlášt o žánre umeleckej literatúry [RYČLOVÁ 2006; RYČLOVÁ 2013].

\section{Apokalypsa nášho veku}

Nespokojnost̉ ruskej inteligencie, ktorá hladala príčiny a vyslovovala následky, ale obzvlášt citlivo reagovala na prejavujúce sa dôsledky udalostí na prelome prvých dvoch - troch desatročí 20. storočia na kontinente i vo svojej krajine „zhrnul“ Vasilij Rozanov, filozof a literát, do práce Apokalypsa nášho veku [ROZANOV 2012]. Spis Vasilija Rozanova má analyticko-argumentačnú hodnotu a po súčasnost’ si uchoval schopnost̉ byt konečnou správou o názorových, ideových, subjektívnych trápeniach nielen svojho autora. Viac ako o dobe si uchováva fundovanú výpoved' o vzdelancovi onej doby, ktorý denne - súc presvedčený, že za svojich súčasníkov riešil nesúlad medzi sebou a svetom, vierou a kultúrou, medzi tým, čo označil za národné a univerzálne hodnotové. V podstate témy a problémy, ktorým sa venuje text, sú osobnou apokalypsou tvorcu, ktorý sa zmietal medzi zanikajúcou minulostou a dravou prítomnostou: „Rusko sa zrútilo za dva, nanajvýš za tri dni [...]. Je zarážajúce, ako sa v okamihu rozsypalo na kúsky. Pritom ešte nikdy predtým taký otras nenastal, nevynímajúc ani velké stahohovanie národov [...]. Zmizla pritom nielen ríša medzi svojím presvedčením o dejinami overenom chode ruskej spoločnosti a o zmätku, ktorý so sebou priniesli tí, na ktorých sa odveký chod cárskej spoločnosti udržiaval: ,Ale čo tomuto >úctyhodnému mužíkovi< cár vlastne vyviedol?"“ [ROZANOV 2012, 11]. Ruský lud sa podla Rozanova dostal do súkolesia viery a jej porušovania, do dramatického postoja krestanstva voči judaizmu, do klamlivej roly kultúry a ruskej literatúry, ktorá podla jeho verdiktu zavádzala ruského človeka a naučila ho apatii aj naivite: „My sme sa zahrávali najmä v literatúre. ,Ako dobre to napísal'. A vždy bolo dôležité iba to, a že to tak ,dobre napísal', ale čo ,napísal', o to sa už nezaujímal nik. Po obsahovej stránke je ruská literatúra taká ohavná, nehanebná a bezočivá ako nijaká iná literatúra. Čo vlastne urobila v rozlahlej a silnej ríši s pracovitým, vynaliezavým a povolným ludom? Ani ho neučila, ani ho nepodnecovala na vykovanie klinca, zhotovenie kosáka, či vyrobenie kosy [...]. Od čias Petra Velkého tento lud vyrastal v úplnej zaostalosti, pričom aj literatúra sa zaoberala iba tým, ,ako lúbili“ a ,o čom sa zhovárali'. A všetci sa len ,zhovárali“ a ,zhovárali` a len ,lúbili‘ a stále iba ,lúbili`“ [ROZANOV 2012, 12].

Do tejto rozhnevanej, osobne motivovanej výpovede o dejinách, ideách, o funkcii ruskej literatúry zahrnul Gogola („Ten diabolský Gogol’ má pravdu“ [ROZANOV 2012, 9]), Dostojevského, Turgeneva, Leva Tolstého a jeho Vojnu a mier, aby sa odkazom na texty vrátil k svojej pamäti a ruskej literatúre; azda aj preto začne otázkou: „Čo my vlastne vieme? Nuž, ako vidno, vieme ,lúbit', ako lúbil Vronský Annu, Litvinov 
Irinu, Ležnev Lízu a Oblomov Olgu“ " ROZANOV 2012, 12-23]. ${ }^{6}$ Pointou po tomto prejave osobnej nespokojnosti s ruskou literatúrou a jej sujetom i postavou, je odkaz Rozanova na inú, do ním aktualizovaného reálu z príkazov krestanskej náuky, na lásku $\mathrm{v}$ ruskej rodine, ktorá sa vytratila. Rozanov patrí medzi tých literátov, ktorí sa zúčastnili podla jeho zhodnocovania svojimi textami na tak rýchlom rozklade ruskej ríše, hovorí o dvoch či troch dňoch potrebných na zánik cárskej politickej a personálnej moci a na rozpad „Velkého Ruska“, a tak vyratúva aj autorov, ktorých umenie a tvorbu rešpektuje a priraduje ich k zlatému fondu ruskej cárskej kultúry: „Pritom Puškin, Žukovskij, Lermontov, Gogol', Filaret - akí to žiariaci ludia ríše" [ROZANOV 2012, 9]. Skutočnost', že je Rozanov akademickým vzdelaním, poznaním nasýtený a v diskusiách ostrielaný filozof, rozhladený literát a intelektuál známy a cenený v staroruskej spoločnosti, sú jeho úvahy, dôvodenia i argumentácie emotívne, a tak subjektívne, že by vlastne nemali získat viac racionálnej pozornosti, ako si vyslúžili vtedy, ked Apokalypsu po prvý raz zverejnil, a predsa sú jeho hodnotiace postoje nadčasové voči dejinám aj prítomnosti krestanskej filozofie, vierouke, morálke a oddanosti ústredným gnómam humánneho učenia: „Lebo najprv musí príst’ odpadnutie a zjavenie sa človeka neprávosti, syn zatratenia, ktorý sa protiví a povyšuje nad všetko, čo sa nazýva Bohom, alebo čo sa uctieva tak, že sa posadí do chrámu Božieho a bude sa vydávat za Boha" [ROZANOV 2012, 99]. Z dominantných tém Vasilija Rozanova v Apokalypse nášho veku - ruská ríša, ruská cirkev, ruskí panovníci, ruskí lud, ruská kultúra a ruská literatúra - sa pozornost̉ vzdelanca v záznamoch a reflexiách dotýka existenciálnych udalostí, ktoré sprevádzajú aj podmieňujú latentne život človeka, a tak sa pýta, „Prečo vlastne zomierame?“ [ROZANOV 2012, 15], aby odpovedal na otázku rezultátom: „Zomierame kvôli jedinej základnej príčine: lebo si nectíme seba samých. My vlastne páchame samovraždu. Nevyháňa nás ani tak ,slnko', vyháňame sami seba" [ROZANOV 2012, 15]. Slnko, tma, svetlo, príroda, to sú dalšie komponenty Rozanovho nazerania na ruského človeka, voči ktorému stavia nihilizmus: „[...] to je to slovo, na ktoré ruský človek už dávno prekrstil seba samého, alebo presnejšie, ktorým sa uvolnil spod kríža" [ROZANOV 2012, 15]. Privolanie si „zbytočného človeka“ do kaleidoskopu osobných tenzií a rozčarovaní z dejinného ruského človeka Vasilij Vasilievič Rozanov ${ }^{7}$ iba uzatvára svoj pôvodný kruh z času, osobností, ideí a reálií, ktoré videl, počul, reflektoval a je možné, že svoju nádej a silu krestanskej viery a z nej odvíjanej odvahy, ako hladat pravdu a žit, v súlade s ňou premyslene, a týmto vlastne ponechal svoj duchovný a nazerací odkaz budúcnosti a potomkom.

6 Prekladatel’ v poznámkach pod čiarou jednotlivé dvojice postáv verifikuje s ich autorom a názvom literárneho textu. V tejto súvislosti teba vyjadrit uznanie prekladatelovi, ktorý opatril vysvetlivkami dobové reálie, postavy a súvislosti, čím text Apokalypsy dostáva punc učiaceho textu pre potomkov.

7 Do českej kultúrnej praxe v preklade vstúpili tieto texty: Apokalypsa naší doby (1997), Spadané listy (1997), Svět ve světle ruské ideje (1999). 


\section{Slunce mrtvých}

Pôsobenie autentického zážitku v beletrizovanej výpovedi zasiahne nielen poznanie, ale výrazne aj existenciálne vedomie krehkej hrany medzi životom a jeho zánikom, dokáže personalizovat’ v príbehu uložený rodinný, rodičovský, susedský zážitok do mravnej a citovej polohy vyrovnávania sa s minulostou. Popri mnohých ruských textoch tematizujúcich desiate až dvadsiate roky minulého storočia $v$ Rusku, dostáva sa Slunce mrtvých Ivana Sergejeviča Šmeljova na vrchol literárnej pyramídy tým, čo chce prostredníctvom autentického zážitku vtesnat do termínu ruskost'. Pre Šmeljova vo vyhrotenej existenciálnej a existenčnej situácii sa zlievajú do tohto termínu či javu viaceré entity, reč, vlast', územie, profesia, potomkovia, hodnota ducha a tradície etnika, istota kultúry, duchovnost pravoslávia, ruská inteligencia, ruský pracovitý človek, medziludské vzţahy, more, Jalta, Krym, aby sa entity rozbíjali o vojnovú revolučnú realitu, primitívnost', násilie, o zverstvá vyhladovaných vojakov, námorníkov, bezmenných susedov, bezmocne ustupovali pred vládou vojny, vraždenia a tupostou politických a vojenských realizátorov nového života svojím jediným zámerom: vzdorovat realite vôlou prežit v nedôstojných podmienkach, a tak unikat’ pred ničením zvyškov ludskosti. Moc davu voči bezmoci jednotlivcov upevňuje navyše zrada, udávanie, strach, vraždenie, okrádanie, teda hmatatelná bezmocnost̉ voči zvrátenostiam samozvancov novej revolučnej moci (na Kryme Bela Kuna a Alexandra Kollontajová). Osvietené jestvovanie ludskosti, kultivovanosti, obety, pomoc, vzájomná ochrana a obrana pred vojnovými tažkostami a stupnuujúcou sa bezohladnostou samozvanej moci revolučného proletariátu sa overuje na takých prostých potrebách života, ako sú jedlo, zdravie, teplo, prístrešie. Autobiograficky vystužené rozprávanie v Slunci mrtvých, popri naturalistických záznamoch z každého z režitých dní, vykročí do zovšeobecňujúcich súvislostí vtedy, ked’ autor a rozprávač jasne naznačia, lebo vedia, že všetko, čo, ako a prečo nivočí nejestvujúce cárske Rusko a vyčkávajúco hladí na spôsob, akým vzniká krajina sovietov, pretože i toto dianie má svoje korene aj väzby na kontinent. Európe, sebavedomému kontinentu nedôverovali v Rusku oddávna mnohí, a „Dostojevskij kdysi o milionu lidí řekl, že je ctihodní občané dají z lidské zásobárny na odpis kvůli experimentu, ale spletl se v počtech: dva miliony překročili - a ze světové zásobárny je neodčetli, uvolnili je z ruské špajzky!“ [ŠMEJLOV 2017,89]. Geopolitická a spoločenská zmena na kontinente, dramatické obmeny úniku pred zánikom v cárskom Rusku spájajú nezmyselne vojnami znivočené ludské životy, vláda krutosti, zločinu, neúcta voči životu jednotlivca. Napokon všednostou sa stali zverstvá, ktoré zabudli na učenie viery, druží sa k ním v tých rokoch aj drancovanie bezbrannej Rusi pre tých, ktorí sa jej majetku zmocnia v Amsterdame, Londýne, v San Francisku, a tak Ivan Šmeljov odkazuje, „Dávej si pozor, stará Evropo, ty překupnice! Nepoztrácej nádherný náhrdelník slávy! Kdo ví...?!“ [ŠMEJLOV 2017, 120]. 
Mnohí spisovatelia rozličnými cestami odchádzali z revolučného Ruska do Európy, aby uchránili život, svoj a s ním aj jeho hodnotu, hoci sa im to darilo nerovnako. Medzi nimi bol v dvadsiatych rokoch aj Ivan Šmeljov, a tak vznikla v roku 1923 novela Slunce mrtvých. „To je taková pravda, že to ani nelze označit za umění. Jedná se o první opravdové svědectví o bolševizmu v ruské literatuře. Komu jinému se tak podařilo zachytit beznaděj a všeobecnou zkázu prvních sovětských let válečného komunismu?" ${ }^{8}$ usúdil Alexander Isajevič Solženicyn.

\section{Slídil (Oko) ${ }^{9}$}

Prozaická tvorba Ivana Bunina a Vladimíra Nabokova vznikala v emigrácii po tom, ako opustili v inom čase a inými cestami vojnové a revolučné Rusko, sprevádza ich vzájomný vztah, v ktorom si popri priazni prejavovali autorskú rivalitu. ${ }^{10}$ Vladimír Nabokov lokalizuje literárny príbeh o ruských emigrantoch do Berlína dvadsiatych rokov minulého storočia. Vedla spoločenskej lokalizácie v próze Slídil [NABOKOV 2013] pre ruských a z Ruska pochádzajúcich emigrantov do Nemecka, zvyčajne to býval pre ruskú inteligenciu Paríž, sprevádza svoj literárny text autorským doplnením až vysvetlením, „Př́iběh se odehrává v letech 1924-1925. Občanská válka v Rusku skončila před nějakými čtyřmi lety. Lenin právě zemřel, ale jeho tyranie nadále vzkvétá. Dvacet německých marek je necelých pět dolarů. Mezi emigranty v Berlíně, jak je zachycuje tato kniha, jsou žebráci i úspěšní podnikatelé [...] a samotný vypravěč, který se nehlásí $\mathrm{k}$ žádné třídě, jsou představitelé mnohotvárné ruské inteligence" [NABOKOV 2013, 91]. Protagonista v stave dezilúzie a osobnostnej negácie (vlastnej bizarnosti) sleduje (akoby z odstupu či nadhladu) svoj norme sa vymykajúci typový, mravný, vztahový a spoločenský rozklad, ktorý má existenciálne fakty (politickej, ekonomickej, spoločenskej) vyvolávajúce (ne)istotu o správnosti a účinnosti emigrácie pred mocenskými praktikami sovietskej reality, čím sa udržiavajú aj v cudzom, spoločensky chladnom až nepriatel’skom prostredí pôvodné sociálnej traumy, ale aj sny, spontánne sa skúšajú nezmyselnej (nelegálnej) aktivity, ako prežit. Pointou sporu medzi predstavou a skutočnostou pri protagonistovom hladaní spôsobov, ako existenčne prežit v emigrácii, je nepríjemná a neadekvátna rola stat’ sa domácim vychovávatelom dvoch nezvládnutelných ruských chlapcov, detí

8 Prevzaté z prebalu [ŠMEJLOV 2017, 120].

9 V anglickom preklade text mal názov Oko. Nabokov v texte Předmuluva $k$ anglickému vydáni zverejnil: „Ruský titul této novely zní Sogljadatajm vysloveno s přízvukem na předposlední slabice, Jde o starý vojenský termín označující ,vyzvědače nebo ,porozovatele', avšak ani jeden z těchto výrazů nemá tak poddajný rozmach jako ono ruské slovo. Poté co jsem si pohrával s,emisarem ‘ a ,gladiátorem', zanechal jsem snahy smísit smysl a zvuk a spokojil se s posledními dvěma hláskami, z nichž se vylouplo anglické eye, a teda ,oko“" [NABOKOV 2013, 89].

10 Vzájomnému vzt’ahu a ich života v emigrácii sa venuje Maxim D. Šrajer [ŠRAJER 2016]. 
emigrantov, a to aj napriek skutočnosti, že ním lomcuje pocit nepriatel'stva voči svojmu ruskému a berlínskemu spoločenskému a zúfalému osobnému sociálnemu postaveniu. Postavu vychovávatela $\mathrm{v}$ jeho spore so sebou samým zvýrazní udavačská konšpirácia a frustrácia z romanticky prežívanej erotickej lásky voči nevýraznej ruskej žene. Trasovisko z predstáv a reality, zo silnejúcej osobnej frustrácie zo živorenia v emigrácii iniciuje latentná osobnostná kríza, ktorú subjekt prežíva v úzkej ruskej, ale majetkom a postavením v cudzine diferencujúcej sa emigrantskej spoločnosti. V Berlíne sa posilnila o prítomnost̉ vízie o iracionálnej osobnej integrácii do spoločenstva zdatných ruských emigrantov, ktorí sú zovretí neprípustnými rodinnými, osobnými, citovými, ekonomickými vztahmi. Cudzie (nemecké) odmietajúce prostredie vnucuje emigrantom indície nepriatel'stva, ohrozenia, strachu, zbytočnosti a posilňuje kolektívny pocit stroskotania, straty osobnej hodnoty, ktorú v emigrácii nové prostredie to dávne ruské už neakceptuje, čím sa stupňuje poznanie osobnej aj etnickej beznádeje v neruskom prostredí. Časová a priestorová tektonika príbehového podložia Slídila vnáša voči typu, funkcii, aktivitám a zmyslu (ne)jestvovania protagonistu obsahy takých pojmov, ktoré podporia nazeraciu stratégiu autora, spomedzi nich na počiatku ide o sebaúctu. Tá sa tematicky motivuje v reálnom aj ireálnom literárnom priestore pre protagonistu ako výsledok sebaúcty utváranej zo spôsobu a aktuálnosti svojho priebežného sebazhodnocovania, teda ako následok latentne prepájaného impulzu medzi materiálnym ja, sociálnym ja a duchovným ja. V naračnej línii protagonistu sa stupňuje a súčasne aj znejasňuje proces tenzijného sebahodnotenia, z neho sa odvíja relativizovanie vlastného mravného uplatnenia sa voči inej mužskej ruskej postave (Chruščov, Roman Bogdanovič, Weinstock, Muchin, strýko Paša z Londýna). Problém hodnoty ako osobnostného prejavu identity aj želanej autonómnosti postavy na presadenie vlastnej či osobnostnej hodnoty ako súčasti pri utváraní alebo rezignácii narastá, ale aj upadá podla okolností pri uvažovaní o personalizovanom zmysle, obsahu, hodnote, význame života v problematických existenčných podmienkach neruského sveta a neruského zmýšlania o tom, čo je podstatné. Predstavou o osobnej ukojenosti v mozaikovito organizovanej berlínskej ruskej emigrantskej spoločnosti sa indikuje poznanie alebo zážitok utvárajúci, alebo relativizujúci prejav osobnej spokojnosti či nespokojnosti so sebou samým, alebo s aktivitami, ktoré protagonista uskutočňuje. Otázku sebahodnotenia protagonista (rozprávač v tretej a potom v prvej osobe, Smurov) opakovane asociuje v každej vypätej situácii ako komponent na utváranie a presadenie si vlastnej identity, no dotiahne ju len po kultúrne a literárne alúzie či podobenstvá, ${ }^{11}$ čím vedome pripravuje koncept svojej mravne nízkej stratégie:

11 Vladimír Svatoň v práci Román v souvislostech času [SVATOŇ 2009] pripomína odkazy a iniciácie z A.S. Puškina M.J.Lermontova, Th. Manna, A.P.Čechova, F. M. Dostojevského, M. Gorkého, N. Gogola, ale aj iných. Kamila Chlupáčová v doslove vo vydaní Slídil (2013) je dôraznejšia, ked pripomína Dostojevského, upresňuje alúzie na Zápisky z podzemí, Zločin a trest, Běsy, ale 
„Jak je dobře známo (abych použil proslulé ruské slovní spojení), mé knihy jsou nejen obdařeny naprostou absencí společenského významu, ale jsou i mýtuvzdorné [...]" [NABOKOV 2013, 91]. Vladimír Nabokov posúva v texte Slídil mieru dejinnej, osudovej či autentickej frustrácie z udalostí sprevádzajúcich zánik starého Ruska a mocenský nástup proletariátu do polohy, $\mathrm{v}$ ktorej jav emigrácia demonštruje na spoločenskom diferencovaní, odlišnosti, rozkladaní sa toho, čo už nejestvuje, ale silou mocou sa chce presadit v neruskom prostredí ako spoločenská entita. Irónia, karikatúra, odstup, drsnost', neláskavé obnažovanie spoločenskej a vztahovej masky, zámer prostredníctvom fikcie/úniku z reality nájst’ s protagonistom vstup do inej a drsnej reality, pritom nič sa nedá zmenit na tom, že cudzinec v cudzine zostáva navždy cudzí a neželaný. A v tom spočíva neliterárna odpoved Vladimíra Nabokova na naivne pochopený ruský zámer o úspešnom živote v emigrácii. Otázka, ako fikciou ruskosti udržat staré časy s vžitými pravidlami, napriek tomu, že čas sa nedá zastavit, si vypomáha ironizovaním sentencie, panta rei, lenže tá platí všade a pre všetkých.

\section{Továren̆ na nového človeka}

Po vydaní osobných denníkov, ktoré vznikli za života Ali Rachmanovovej ${ }^{12} \mathrm{v}$ Rusku do roku 1917 a po ňom, kým neodišla (v roku 1924 vykázaná) do Európy so synom a rakúskym manželom, jej rozhodnutie napísat román Továreñ na nového človek $a^{13}$ pôsobí dvojako, bud ako autorkina karikatúra toho, s čím by sa nedokázala v sovietskom Rusku zžit, a to by po jej osobných skúsenostiach bolo nanajvýš prirodzené, alebo ide o autorkin zámer $\mathrm{z}$ dialky a z odlišného spoločenského systému porozumiet krajine, ktorú vnútorne neopustila. A tomu by sa tiež dalo porozumiet ako autorkinej ambícii porozumiet tomu, čím je nové Rusko iné, lepšie, zdatnejšie než staré Rusko, v ktorom vyrastala: „Socialistická ríša dobra“ sa odvoláva na učenie Karola Marxa, ktoré sovietsky proletariát chce uskutočnit', „Musíme vybudovat našu vlastnú vedu, našu vlastnú filozofiu, našu vlastnú morálku a nahradit ňou staré rozpadajúce sa náboženstvo. Musíme založit nové náboženstvo, náboženstvo proletariátu“ [RACHMANOVOVÁ 2017, 167]. Doslov Prekrásny nový

pripomína aj: „Sít literárních vztahů novely je široká, kromě světových autorů (Proust, Goethe, Poe, E. T. A. Hoffmann) integruje Nabokov do textu množství prvků z ruské klasické literatury (Puškin, Gogol, Lermontov, Někrasov, Dostojevskij). Už text této rané novely tak ukazuje, kdo je Vladimir Nabokov" [NABOKOV 2013, 91].

12 Ala Rachmanovová, vlastným menom Galina Džuraginová (1898 - 1991), je autorka prác Študenti, láska, Čeka a smrt'. Denníky z rokov 1916-1920; Manželstvá v červenej búrke. Denníky z rokov 1920 - 1925; život vo Viedni zachytila v publikácii Mliekarka z Ottakringu. Denníky z rokov 1925 - 1927. Súborne vyšli pod názvom Ruské denníky.

13 Ala Rachmanovová za román získala v roku 1935 cenu Académie d’Education v Paríži za „najlepší antibolševický román“. Autorka doslovu Demjánová naznačila, odvolávajúc sa na korešpondenciou A. Rachmanovovej s manželom, že očakávala nomináciu na Nobelovu cenu za literatúru. 
svet [DEMJÁNOVÁ 2017, 251-268], jeho autorka a súčasne aj prekladatelka textu, končí pointou za autorku: „Ala Rachamanovová sa pokúsila sovietske Rusko dobyt'. Po svojom. Slovami a príbehmi“" [DEMJÁNOVÁ 2017, 269]. V čase prvého vydania románu sa tak nemohlo stat', popri technických príčinách rozhodujúca bola ideová a ideologická línia textu, ktorá spočívala v základnej téze, s ktorou autorka pracuje, v literárnom konfrontovaní spoločenských, rodinných a kultúrnych hodnôt starého Ruska s mocensky inštalovanými hodnotami (kolektívneho) človeka v novom Rusku. Autorka pri ich literárnom etablovaní prostredníctvom prelínania sujetov (žena muž) postáv zo starého a nového času jestvovania ruskej spoločnosti tak robí na jednotlivostiach (zákon, norma, nariadenie, predpis, zákaz) praktickej politiky sovietskeho vedenia. $\mathrm{V}$ tematizovaných reáliách $\mathrm{z}$ dvadsiatych rokoch rekonštruuje činy spoločnosti a jej zámer vychovat prototyp nového človeka (ženy) v Rusku, čo pre bolševikov znamenalo „starého človeka zlikvidovat. A nielen to - chceli aj zahladit jeho stopy, zničit všetko, čo by ho mohlo pripomínat" [DEMJÁNOVÁ 2017, 254], aby sa po čase vo svete pre nového občana udomácnilo pomenovanie homo sovieticus. ${ }^{14}$ Rachmanovová prepojila realistický a romantický skelet príbehu pre svoje rozprávanie, prostredníctvom vzt̉ahu (modelová postava) súdruha Vladimirova, ten riadi praktickú továreň na výchovu nového človeka a pracovníčky z jeho administratívy, spoločensky poznačenej „bielej“ Tane. Rachmanovová takto prosto, čierno-bielo, konfrontuje dva spoločenské a rodinné, myšlienkové, vzdelanostné, mravné, kultúrne, hodnotové a estetické systémy, ktoré „produkujú“ svojich nositelov. Kompozičný princíp konfrontácie predurčuje morfológia románu, naznačuje typológiu postáv starého a nového sveta a anticipuje výsledok ich sujetu, čím sa emotívne ladeným porovnávaním venuje demaskovanou násilia, zvôle, hlúposti, arogancie a manipulácie štátnych nástrojov / inštitucionálnych mechanizmov vytvorených na revolučnú, aprioristickú premenu starého Ruska na sovietske Rusko.

Tanin osobný príbeh patrí medzi triviality lacnej romantickej prózy: kultivované rodičovské zázemí, vzdelanie, revolúcia, úradnícka práca, znásilnenie nadriadeným, diet̉a, jej oddanost̉ a láska k mužovi - násilníkovi, ktorého zničí ním utváraný systém na výchovu nového človeka. Hodnoty partnerské a rodinno-vzṫahové sa dostanú do jednej línie - vdaka oddanej láske ženy Tane, ktorá sa obetavost̉ou a oddanostou chystá prevychovat manžela revolucionára. Láskou, oddanost̉ou, obetavost̉ou a pokorou

14 Termín vytvoril rusky disident Alexander Zinoviev, „Podla neho je svojou podstatou oportunista, žije podla zásady: Všetko je společné, a teda nič nepatrí nikomu. [...]. Homo sovieticus nemá identitu, jeho etnický pôvod je vygumovaný. Jeho domovom je Zväz sovietskych socialistických republík ako celok. Je obozretný. Na úradoch sa neháda, radšej prehltne urážku a ide domov, protože verí tomu, že by mohol pochodit aj horšie. A má pravdu. [...] zamýšlaný koncept z komunistickej propagandy dvadsiatych a tridsiatych rokov 20. storočia: proletár s čistým štítom, ktorý sa vzdeláva a pracuje na sebe, nadčlovek, ktorý nie je lenivý, nepodvádza, nekradne, nepije, neklame“ [DEMJÁNOVÁ 2017, 256-257]. 
chce ochránit súdruha Vladimirova pred ním samým a pred svojvôlou a drastickými praktikami nového systému, v ktorom je možné a dovolené všetko, čo je iné, ako to bolo v Rusku predtým. Rachmanovová zorganizovala čierno-bielou technikou na schéme poklesnutého romantického príbehu presvedčivú drámu jednotlivca v okolnostiach, ktoré nežičia prirodzenému životu, kde niet dobra a lásky, chýba prirodzená úcta k žene, ludskost̉ už dávno premohli hrubost̉ a násilie, mravy ničí mocou odporúčaná volná láska, legalizované potraty, divoká sexualita, nevážny postoj $\mathrm{k}$ manželstvu, rozvodovost̉ ako nezáväzná spoločenská hra nových ludí v nových časoch. Rozprávačka má dostatok času na svoju mravnú a citovú misiu, ale aj vhodne zvolené presuny na objasňovanie pointy vo vzt̉ahoch dalších postáv (zrelí muži $s$ váženým spoločenským postavením versus mladé ženy s ideálmi), ktoré žijú v zajatí antického mýtu o fyzickej kráse ženy a o výnimočnosti umenia. K tejto príbehovej línii sa pripájajú sujety odvíjané z tragickej citovej oddanosti/nevery partnerov, precízne sa konštruuje cesta $\mathrm{k}$ viere, hoci ústi do náboženského sektárstva (autorkina nápoved' o sektárstve v dvoch formách $\mathrm{v}$ živote nových ludí). V schéme, s ktorou Rachmanovová pracuje, popri princípe kontrastu, ponechala ostatné kompozičné nástroje v úzadí a vytvorila pre skúseného čitatela pozadie až dramatickú či tragickú scénickú kulisu z množstva informácií, poznatkov a vedomostí získaných z neliterárnych zdrojov o sovietskom Rusku. Žena ako ústredný problém Továrne na nového človeka uviedla Rachamanovovej rozprávanie (pseudo)romantického príbehu do súkolesia drsných, nehumánnych a nemravných inštrukcií, ktorými sovietsky politický systém uskutočňoval genézu a účinkovanie nového človeka. Realita postavená na utópii obnažila neúctu a bezohladnost̉ voči individualite jednotlivca. Za zmienku stojí odlišný postoj voči literárnej postave a verifikovatelnej revolucionárke Alexandre Kollontajovej; Ivan Šmeljov ju spája so zverstvami na Jalte a Kryme, Rachamanovová, jej postava Tane, s porozumením opakovane pripomína jej koncept pre sovietske ženy ${ }^{15} \mathrm{v}$ novej spoločnosti. Sovietske dobové spoločenské a politické zaklínadlo, je ním všetko, čo označili noví ludia za „buržujský prežitok“, zasiahol do všetkých realizovaných, ba viac, normotvorne presadzovaných kontaktov morálky, zdravovedy, sociálnej a rodinnej gramotnosti, ba aj do práva zasahujúceho do úkonov praktického spoločenského života. Odpovedou sú ňou precízne komponované zrkadlové odrazy, miesto nového človeka nastupuje spoločensky nezvládaný rozvrat v presile zvrátenosti, svojvôle, špekulantstva, zločinnosti, násilia a sektárstva; politicky a mocensky sa politický program výchovy nového človeka upevňuje pod hrozbou pobytu v gulagoch, lágroch a v silnejúcom strachu a s ním spojenej neistoty. Pointou Rachmanovovej trpezlivého zobrazovania toho, ako funguje nový ruský systém s novými nositelmi

15 Autorka adaptovala verifikovatel’nú revolucionárku A. Kollontajovú do roly svojej literárnej postavy, pritom odkazuje na jej dostupný a v danej dobe zverejenený text Tézy o komunistickej morálke $v$ oblasti manželských vzṫahov [RACHMANOVOVÁ 2017, 262]. 
nového sovietskeho človeka si natrvalo uchová rozprávačka a protagonistka Taňa, ked' dostane odpoved: „Vášho manžela sme, žial', museli zatknút. Viete... pre tie záležitosti so sektármi v jeho Továrni. Zdá sa, že ani jeho ideológia nie je celkom v poriadku. Ako som povedal... je mi to vel’mi lúto, ale váš manžel čelí obžalobe z kontrarevolúcie!“ [RACHMANOVOVÁ 2017, 249]. A to je vyvrcholenie Rachmanovovej kultivovanej a poučenej sondy do mechanizmu, ktorý pripravil jednu z možných podôb budúcnosti nového Ruska. Obrazne je to aj chvíla pravdy pre neliterárnu projekciu objektívneho dejinného a spoločenského procesu a aktualizované pripomenutie si sentencie, ked' revolúcia požiera svoje deti.

\section{7}

Román 2017 [SLAVNIKOVÁ 2011] sa sústreduje na zložité spoločenské a osobnostné problémy súčasníka v Rusku posledných desatročí. Olga Slavniková príbeh kompozične organizuje ako dejinnú kontinuitu spoločenského, politického, ekonomického, etnického, mravného ako tých javových súčastí systému, pre ktorý sú určujúce súvislosti, odvíjané od hodnotovej tradície a mravnej kontinuity histórie a nimi utváraného vedomia, kam patrí nielen sociálna, ale pre potomkov predovšetkým rodová pamät. Napokon platí, že všetko so všetkým súvisí obsahom aj hodnotami uloženými do pamäti národa a jeho dejín. Látka a tematika románu 2017 naznačujú, že sa postavy rozličného veku, profesií a osobných príbehov a problémov ani v obrysoch svojich životov nemôžu dištancovat’ od minulosti, tej dávnejšej i nedávnej spred pár desat’ročí. Minulost̉ národa žije $\mathrm{v}$ jeho jedinečnej entite, $\mathrm{v}$ praktikovanej morálke a v žitých hodnotách, v tých spoločenských aj personálnych. Žánrové kontúry textu 2017 aktualizujú postupy historizujúceho, rodinného, lúbostného, sociálneho, vojnového, dobrodružného, kriminálneho, folklórneho, naturistického morfologického postupu, do ktorého sú funkčne zakomponované zložité osudy postáv. Látka autorkou vyňatá a spresňovaná faktografiou $\mathrm{z}$ historiografie a tradície uchovanej v sociálnych dejinách konkrétneho spoločenstva sa stala významným literárnym artefaktom prijímania, filtrovania a vyhodnocovania príčin a následkov zo života a dejov generácií sovietskych a ruských ludí minulého a súčasného storočia. Autorkina, predovšetkým hodnotovo a mravne pointovaná výzva na poznanie a premýšlanie o tom, čo patrí minulosti a s čím musí počítat prítomnost sa ustaluje na želaní nerezignovat ako národ, mladá generácia a nie vždy iba úspešný jednotlivec na hodnoty, ktoré ruskú spoločnost', jej prirodzenú úctu k žičlivému životu pre všetkých občanov neohrozujú do budúcnosti. Žánrom hybridný text aj autorkina zložito rozvíjaná nazeracia a kompozičná stratégia vytvorili dostatočný priestor $\mathrm{v}$ čase na to, aby sa zachytil literárny príbeh ako proces utváraný z kombinovania náročného hodnotového, mravného a estetického prelínanie sa nízkeho a vysokého. Mozaikovito utváraný príbeh zo sociálneho statusu 
so sociálnym zázemím obyčajného formoval výzvu znova premýšlat o účinnosti mýtu o velkej krajine a o jej slávnych Dejinách. Autorka zvolila napätie konštruované prostredníctvom sujetu ako presvedčivé iniciačné východisko, ktoré zasiahne do tvaru žánrového hybridu a do nazeracej otvorenosti narátora pri kontakte, ked'sa prepája literárne a neliterárne (politologického, historiografického, sociologického, kultúrneho, etnického) problémové a motivické podložia, a to preto, aby sa mohol uskutočnit ústredný myšlienkové status: stratégia zvolená na organizovanie fabuly sa konfrontuje s ideami národných dejín velkej a posledné tri desatročia aj nepokojnej krajiny, v ktorej napriek zložitým vývinovým okolnostiam pretrvávajú vo vedomí spoločenstva ustálené humánne a kultúrne ideály.

Autorské texty, ktoré zachytávajú, zaznamenávajú, alebo odkazujú na to, čo prežili ruskí autori, ktorí podstatnú čast svojho života boli spätí s cárskym Ruskom a $\mathrm{z}$ odlišných príčin, $\mathrm{v}$ nerovnakom čase, ale predsa odišli do Európy pre vojny bielych s červenými, pre kruté vyčíňanie vojenských, partizánskych a samozvaných jednotiek po území krajiny s rozpadajúcim sa systémom, ale i preto, že nenachádzali perspektívu pre seba, rodinu a svoju prácu v nových podmienkach sovietskeho Ruska. Alexander Solženicyn ten čas, tú dobu nazval prvé roky sovietskeho vojnového komunizmu. Estetiku a poetológiu zvolili autori v priamej väzbe na svoje umelecké ambície, ale aj pod tlakom akútnej látky a autobiograficky profilovanej tematiky. Autentickost', autobiografickost', dokumentárnost', to sú podložia, z ktorých vznikali autorské texty staršej literárnej generácie. A z nich preniká do súčasnosti poznanie o personálne posilnenom vedomí, ale aj o nepokoji zo straty tých hodnôt z osobného a spoločenského života, ktoré majú svojskú históriu a predchádzali životu aj v starom Rusku. Spomedzi nich sa tradícia staroruského života aj s novotami v hodnotovom, mravnom, odbornom, spoločenskom a mocenskom riadení sovietskeho života lámu do priehrštia tematizovaných situácií o tom, čo majú generácie predkov za sebou a tie nové sa s odkazom musia vyrovnał tak, aby sa nevytratila úcta k človeku a životu v jeho obsažnosti. Hodnota a jej uplatnenie v spoločenskom systéme si, odvolávajúc sa na autorov pripomenutých literárnych textov, dostala medzi želané, očakávané a draho vykupované súčasti života v ruskej a sovietskej spoločnosti v minulom storočí, na ktoré, o tom vypovedá aj román 2017, dolieha minulost’ svojimi rozkolísanými normami. Hodnota uložená do jednotlivca, do národného spoločenstva sa nemusí za zložitých okolností pre spoločnost̉ ako celok zbližovat’ s hodnotami kultivovaného a interne ustáleného spoločenského systému. 


\section{Literatúra::}

ČERVENKA, M. a kol. (2005): Na cestě ke smyslu. Poetika díla 2o. století. Praha.

DEMJÁNOVÁ, Z. (2017): Prekrásny nový svet. In: RACHMANOVOVÁ, A.: Továreñ na nového človeka. Bratislava, s. $251-268$.

DOHNAL, J. (2012): Proměny modelu světa v ruské próze na přelomu XIX. a XX. století. Brno.

FELDEK, L. (1982): Homo scribens. Bratislava.

NABOKOV, V. (2013): Slídil. Přeložil Pavel Dominik. Praha.

POSPÍŠIL, I. (2013): K teorii ruské literatury a jejím souvislostem. Brno.

PRUDKÝ, L. a kol. (2009): Studia o hodnotách. Praha.

RACHMANOVOVÁ, A. (2017): Továreň na nového človeka. Preklad z nemčiny Zuzana Demjánová. Bratislava.

RYČLOVÁ, I. (2006): Ruské dilema. Společenské zlo v kontextu osudů tvůrčich osobností Ruska. Brno.

RYČLOVÁ, I. (2013): Mezi kladivem a kovadlinou. Dvacáté století v osudech literárních osobností Ruska. Brno.

ROZANOV,V.V. (2012): Apokalypsa nášho veku. Vybral a preložil Mikuláš Šoóš. Bratislava.

SLAVNIKOVÁ, O. (2011): 2017. Preložila Zuzana Lorková a Igor Otčenáš. Bratislava. SVATOŇ, V. (2009): Román v souvislostech času. Praha.

ŠMELJOV, I. S. (2017): Slunce mrtvých. Překlad Jakub Šedivý. Praha.

ŠRAJER, D. M. (2016): Bunin a Nabokov. Príbeh súperenia. Bratislava.

\section{About the author}

Viera Žemberová, University of Prešov, Faculty of Arts, Institute of Slovak and Media Studies, Prešov, Slovakia, viazember@gmail.com 
